\title{
TEACHERS IN THE IMPLEMENTATION OF PRACTICAL AGRICULTURE CURRICULUM IN KENYA'S ARID AND SEMI ARID SECONDARY SCHOOLS
}

Miriam N. Kyule

Egerton University, Kenya E-mail: kyule11@gmail.com

Jacob J. J. O. Konyango

Machakos University, Kenya

E-mail: jaonyango2003@yahoo.com

Agnes 0. Nkurumwa

Egerton University, Nakuru, Kenya E-mail: aonkurumwa@yahoo.com

\begin{abstract}
One of the major challenges of the $21^{\text {st }}$ century is the increasing level of academic qualifications at the expense of relevance in education. School agriculture is one of the subjects which require teachers who as the principal implementers of the curriculum must be able to interpret agriculture curriculum objectives to meet societal needs. However, implementation of agriculture curriculum in Arid and Semi Arid Land (ASAL) secondary schools has fallen short of its expectations as it has not significantly influenced agricultural activities both in school and surrounding communities. Thus, the benefit of implementing agriculture curriculum in ASALs is yet to be fully achieved. The research sought to document the teacher factors influencing implementation of secondary school agriculture curriculum in ASAL schools in Kenya. The research focused on teacher training, teacher technical knowledge and skills about Dry Land Agriculture [DLA] practices and training and support. The research was carried out in ASAL counties of Baringo, Makueni and Narok. Survey research design was used. The researcher developed a semi-structured questionnaire to obtain data on the teacher factors from 88 agriculture teachers. The research results showed that most teachers were trained and professionally qualified thus expected to translate the curriculum objectives to learning activities relevant to ASALS. However, agriculture teachers were found to be deficient in terms of technical knowhow on DLA practices among them, insitu water harvesting and use of sunken beds. Agriculture teachers received insufficient support towards professional development. The support did not aim at DLA knowledge and skill enhancement towards agriculture curriculum implementation. Agriculture teachers' inadequacy on DLA practices' technical knowhow and lack of support towards professional development was impacting negatively on agriculture curriculum implementation in ASAL schools. The Government has a responsibility of ensuring that all ASAL schools are staffed with qualified teacher. Secondary school administrations in ASALs need to support teachers on continuous trainings that are relevant to agriculture curriculum implementation. Agriculture training program developers need to focus more on the acquisition of technical know on all DLA practices. Addressing the training inadequacies among agriculture teachers in ASAL schools will lead to a competent staff who can translate curriculum objectives into learning experiences that promote DLA in ASALs. This translation will in turn influence agricultural activities both in school and in the society for improved agricultural production.
\end{abstract}

Keywords: agriculture teachers, curriculum implementation, arid and semi arid lands, dry land agriculture. 
Miriam N. KYULE, Jacob J. J. O. KONYANGO, Agnes O. NKURUMWA. Teachers in the implementation of practical agriculture curriculum in Kenya's arid and semi arid secondary schools

\section{PROBLEMS \\ OF EDUCATION \\ IN THE $21^{\text {st }}$ CENTURY \\ Vol. 76, No. 4, 2018 \\ 534 \\ Introduction}

The teaching agriculture in Kenya's secondary schools is not purely for academic purposes but mainly an endeavor in meeting the developmental needs of the immediate community. Agriculture is and remains the country's economic mainstay as Kenya envisages its transformation into a rapidly industrializing, middle-income nation by the year 2030 (Lewa \& Ndungu, 2012). However, to maximumly exploit the agriculture sector, the education sector has to play its role by preparing human resources who are competent through proper implementation of the agriculture curriculum in schools. Arid and Semi Arid Lands (ASALs) are of concern because they occupy 84 percent of Kenya's land (United Nations Development Programme [UNDP], 2012). Thus implementation of agriculture curriculum in Arid and Semi Arid secondary schools is paramount to equip learners with knowledge and skills to use to make the ASALs productive.

This study was informed by Obonya's (2004) functional curriculum theory. The theory explains that education's purpose is to equip learners with practical knowledge and skills to enable them fit and exploit an environment and the focus in this study is that implementation of secondary school agriculture curriculum will prepare graduates who will be able to utilize ASALs agriculturally. According to Obonya, the learners' environment should determine the way education is carried out, including what is taught and how it is taught and learned. The importance of secondary school agriculture curriculum is relevancy of education for rural development. Elimination of rural poverty as experienced in the ASALS is one of the great public demands. Agriculture curriculum implementation in ASAL schools is meant to equip learners with DLA knowledge and skills they can use to transform agricultural productivity in ASALs.

For the secondary school agriculture curriculum to meet the societal needs, it must continually be reformed since these needs are dynamic. The Kenyan context is therefore relevant to discuss. The introduction of secondary school agriculture curriculum in Kenya secondary schools in 1959 was based on making it more responsive to the rural developmental needs and in this respect agricultural production in ASAL (Konyango, 2014; Moore, 1979). In 1976, the Gachathi Report recommended several policies to enhance the quality and effectiveness of secondary school agriculture curriculum implementation (GoK, 1976). It had strong recommendations in support of agriculture in schools. In addition, to create continuity between secondary school agriculture and the University, a panel was constituted to draw up an 'A' level agriculture syllabus. The school farm being a crucial teaching resource facilitating implementation of practical agriculture, the Ministry of Education (MoE) circulated a policy document on the management of the school farms. The school farm management policy emphasized holiday farm attachment which was a way of providing not only a linkage to the farming profession but also a linkage to the reality and the practicality of farming. This linkage was meant to promote the practical implementation of the agriculture curriculum which would play a role in enhancing agricultural productivity in Arid and Semi Arid schools.

As part of the curriculum reform process the 8-4-4 system of education was rolled out in 1985. One of the criticisms that faced this system was improper training of teachers to handle the technical subjects that were now compulsory in all schools $(\mathrm{GoK}, 1981)$. The system was too expensive to implement hence the Government was unable to meet its financial demands (Mwiria, 2002). This system led to the recruitment of unqualified teachers of agriculture the lack of needed resources for proper curriculum implementation, especially in the ASALs where the government had promised to provide financial support. Additionally, there was an increase of diploma colleges being allowed to train agriculture teachers irrespective of resources or qualified agriculture trainers. Such arrangements for teacher training jeopardized the quality of teachers trained to implement the agriculture curriculum. Thus there is need to document the training level of agriculture teachers implementing the curriculum in ASAL secondary schools. 
Effective implementation of agriculture curriculum is partly a product of good teaching. According to Mwiria (2002) good education depends on good teaching and learning which in turn depends on good teachers. The quality of agricultural knowledge and skills acquired by learners depends on the quality of the teacher since teachers are the pillars in curriculum implementation process. Past studies have indicated that qualified agriculture teachers appropriately interpret the syllabus and are able to determine the concepts to be taught and agricultural skills to be acquired (Sindale \& Dlamini, 2013). For the ASALs to benefit from school agriculture, the agriculture teachers must be well educated and be thorough scientists, rural sociologists and technically competent in agriculture. These are the category of agriculture teachers who would be able to influence DLA practices outside the school to the community and this is a prerequisite for effective agriculture curriculum implementation in the ASALS.

There are many teacher related factors that influence the implementation of agriculture curriculum. A study by Owoeye and Yara (2011) found that, what a given teacher believes and knows highly influences the way they implement the curriculum. The study also established that the teachers' attitude towards a curriculum influences the difference between the intended and implemented curriculum. Other teacher related factors influencing agriculture curriculum implementation include; training level or teacher quality, competence, experience, innovativeness, commitment, experience, teaching load, job satisfaction, monetary and nonmonetary motivation and class attendance (Kirima \& Kinyua, 2016; Mapolisa \& Tshabalala, 2013; Ofoha, Uchegbu, Anyikwa \& Nkemdirim, 2009; Okogu, 2011; Reche, Bundi, Riungu \& Mbugua, 2012; Puyate, 2012). Despite the many factors, this study focused on those that are the key in interpreting the curriculum to serve ASAL areas. These were teachers' technical knowledge and skills on DLA practices, and ability to translate curriculum objectives into appropriate learning activities that promote DLA.

The effectiveness of agriculture curriculum implementation is measured by the outcomes. One of the expected outcomes of teaching agriculture in secondary schools in Kenya is to make a positive contribution to sustainable rural development in the society through integration of relevant agricultural activities in the curriculum. However, implementation of the agriculture curriculum in the ASAL schools has fallen short of these expectations. This could be due to curriculum implementation not being able to adequately integrate the agricultural activities in the curriculum on the school farm which would in turn influence agricultural activities in the surrounding communities. This may be one of the possible reasons which have resulted in under exploitation of the agricultural potential of the ASALs, one of which is the way in which the curriculum is implemented. The broken link between agriculture curriculum implementation in ASAL schools and its expected outcome within the society is not clear. Thus, agriculture teachers being the curriculum implementers, this research sought to answer the question "which teacher related factors influence agriculture curriculum implementation in ASAL schools". If the teacher related factors are identified and possible solutions found, proper implementation of the curriculum is expected to translate to better skilled school leavers and in turn to increase agricultural production in ASALs through adoption of appropriate DLA practices.

\section{Methodology of Research}

\section{General Background}

Survey research design was adopted for this research. The research design was deemed the best since the research was collecting data on an on-going agriculture curriculum implementation process as indicated by Fraenkel and Wallen (2000). This design enabled the researcher to collect data from agriculture teachers on teacher related factors influencing implementation of the agriculture curriculum in ASALs. The data was used by the researcher to document these factors as they were in ASAL schools.

\begin{tabular}{|l} 
PROBLEMS \\
OF EDUCATION \\
IN THE 21 $1^{\text {st }}$ CENTURY \\
Vol. 76, No. 4, 2018 \\
\hline 535
\end{tabular}

(1) 
Miriam N. KYULE, Jacob J. J. O. KONYANGO, Agnes O. NKURUMWA. Teachers in the implementation of practical agriculture curriculum in Kenya's arid and semi arid secondary schools

\section{PROBLEMS \\ OF EDUCATION \\ IN THE $21^{\text {st }}$ CENTURY Vol. 76 , No. 4, 2018 \\ 536}

The research was carried out in the ASAL regions of Kenya. There are four ASAL regions namely; North Eastern, Coast, Eastern and Rift valley. Each of these regions is further divided into smaller County administrative units. Multistage sampling was used in this research. It was appropriate because it enabled the researcher to divide the population into stages, sample the stages, repeating the process until the ultimate sampling units were obtained at the last hierarchical level (Lukman, 2012). Out of the Four ASAL regions, Eastern and Rift valley were purposively selected for this research for they are geographically centrally placed and are more accessible. From these two regions, three counties were purposively selected for this study considering their geographical spread and representation of all other ASAL counties. The three were; Baringo, Makueni and Narok counties. The secondary schools in the three sub counties formed the sampling units for this study. One agriculture teacher from every school in the three counties formed a sample for the study. In case a school had more than one agriculture teacher, random sampling through balloting was done to select only one for the study. A total of 88 agriculture teachers out of a possible 120 participated in the research.

\section{Instrument}

A researcher developed semi-structured questionnaire was used to collect data from agriculture teachers in the ASAL schools. The questionnaire had two sections (A and B). Section A sought to obtain information on the respondents' demographic data. Section (B) looked at teacher related factors that were likely to influence implementation of secondary school agriculture curriculum in ASAL schools. One single item in this section sought to get information on the teacher's training level. The second item had a five point scale and it sought information on teachers' technical knowledge and skills on 20 DLA practices relevant to ASALs.

To ensure the instrument's content validity, each of the items was discussed with the supervisors to ensure that the items fully addressed the objective of the study. A pilot study was done using a sample of 10 teachers of agriculture from Nyahururu Sub County of Laikipia County. The instrument had a reliability of .76 which was estimated using Cronbach's Alpha Coefficient. After obtaining the relevant research permit documentation, the researcher then went to the respective schools, introduced herself to each school principal and with their permission she handed the questionnaires to the agriculture subject teachers. Some of the teachers of agriculture were able to read and respond to the items immediately. However, those who could not and requested for time, a span of two days was agreed upon after which the researcher went back and collected the completed questionnaires. The respondents were informed of their right to confidentiality of the information they were providing after which they signed a consent form.

\section{Data Analysis}

Data was analyzed using SPSS version 20. Descriptive statistics mainly frequencies, percentages and charts were used to present data on the demographic characteristics of the respondents and the teacher related factors influencing implementation of agriculture curriculum in ASAL schools. A scale that was developed by the researcher was used to rate agriculture teachers' level of technical knowhow on practices that promote DLA in ASALs. In this scale, any mean level between 1-1.5 was categorized as very low, 1.6-2.4 as low, 2.5-3.3 as moderate, 3.4-4.2 as high and 4.3-5.0 as very high. 
Miriam N. KYULE, Jacob J. J. O. KONYANGO, Agnes O. NKURUMWA. Teachers in the implementation of practical agriculture curriculum in Kenya's arid and semi arid secondary schools

\section{Research Results}

The teacher related factors focused on were teachers' ability to translate curriculum objectives into learning experiences relevant to DLA by identification of training level, technical knowhow regarding practices promoting DLA in the curriculum and training and support. The results were as follows:

\section{Level of Training}

Training level of the respondents was identified as an indicator of the agriculture teachers' ability to translate the curriculum objectives to address ASAL needs. Asked whether they were professionally trained to teach agriculture in secondary schools, 75 percent responded yes while 25 percent were not professionally trained teachers of agriculture. Thus, the teachers' training level is expected to translate to better agriculture curriculum implementation. The training level for the 75 percent professionally trained teachers is presented in Figure 1.

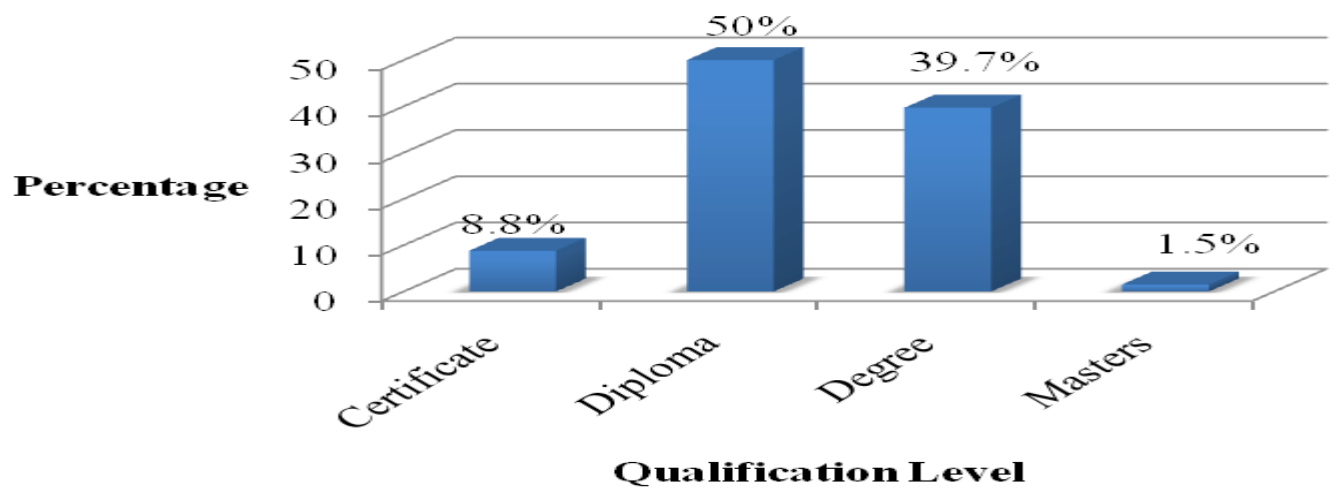

Figure 1. Training level of agriculture teachers in ASAL secondary school.

It is clear that most of the agriculture teachers are diploma and degree certificate holders and qualification level is in line with the expectation of Teachers' Service Commission (TSC) as the body responsible for teacher employment in Kenya. The presence of few certificate holders was an indication that the qualifications to teach in secondary schools in Kenya have improved with time. Additionally, most of the institutions that offered certificate qualifications have either been upgraded to colleges or universities to offer diploma or degree courses.

The level to which the untrained teachers learnt agriculture was sought. The results were as shown in Figure 2.

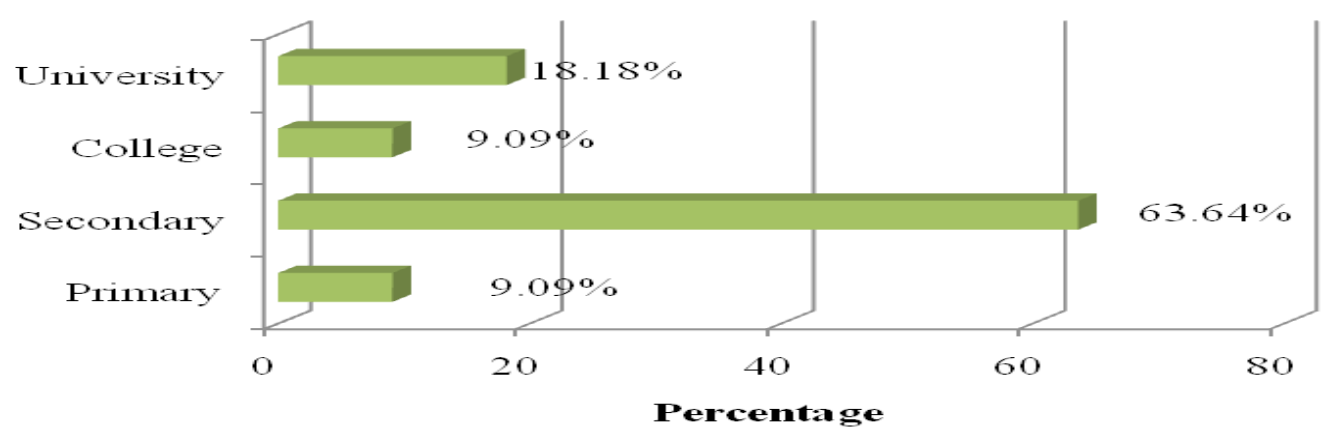

Figure 2. Highest level of learning agriculture for the untrained respondents. 
Miriam N. KYULE, Jacob J. J. O. KONYANGO, Agnes O. NKURUMWA. Teachers in the implementation of practical agriculture curriculum in Kenya's arid and semi arid secondary schools

PROBLEMS

OFEUCATION

IN THE $21^{\text {st }}$ CENTURY

Vol. 76, No. 4, 2018

The results clearly indicate that 72.73 percent of these untrained teachers had studied agriculture up to either primary or secondary school levels. Therefore, they lack the basics of interpreting curriculum objectives into appropriate learning experiences for proper curriculum implementation in ASAL schools. The 27.27 percent with college and university qualifications also lack the professional skills on how to implement the agriculture curriculum. This gap is because they lack the fundamentals on how to interpret curriculum objectives into learning experiences promoting DLA for ASAL development. Thus, the inability to interpret curriculum objectives appropriately to address the societal needs influences the quality of agricultural skills and knowledge transferred to the learners.

\title{
Overall Teacher's Level of Technical Knowhow on DLA
}

On a scale of 1-5, respondents were asked to rate their technical knowhow on DLA. The results are as shown in Figure 3. Over half (61.4 percent) of the respondents have a high level of technical knowhow. The high level of technical knowhow is an indication that teachers are competent enough to implement the DLA practices and skills covered in the curriculum. A percentage of 36.4 had low technical knowhow while 2.3 percent had no technical knowhow on practices promoting DLA. This finding was attributed to the fact that 25 percent of the teachers handling the subject are not trained agriculture teachers hence their technical knowhow on DLA practices and skills is limited. A low level of technical knowhow on DLA practices or lack of it negatively influences the implementation of the agriculture curriculum in ASALs.

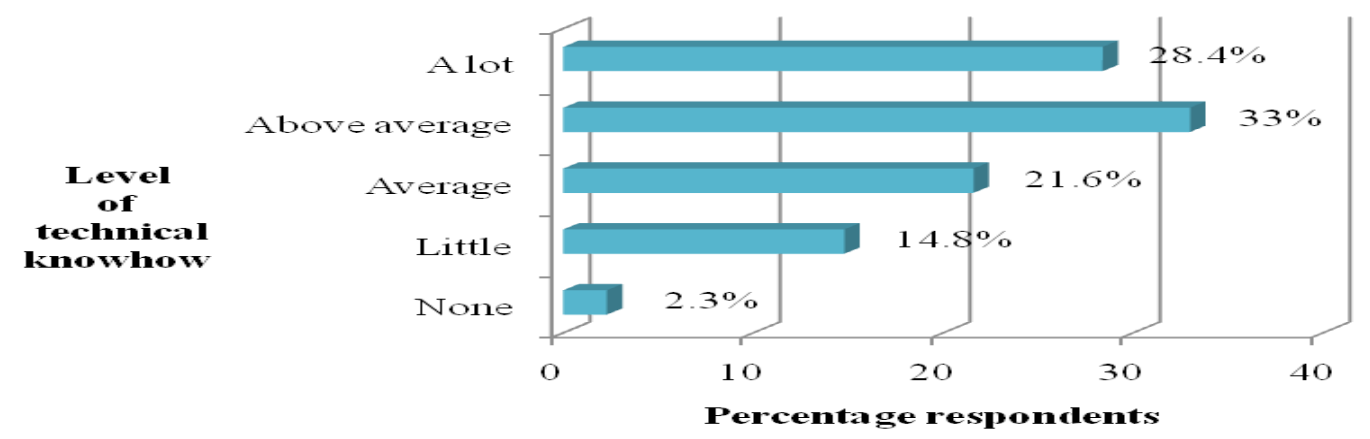

Figure 3. Percentage of teacher's overall level of technical knowhow.

\author{
Teachers Level of Technical Knowhow on \\ Individual Agricultural Practices that Promote DLA
}

Agricultural practices that promote DLA were identified and respondents asked to rate their technical knowhow on each. Twenty items were used and their Cronbach's Alpha was .948. The Alpha indicates the level of consistency with which the use of the same items would yield similar results. The twenty items reflecting DLA practices are as shown in Table 1. 
Miriam N. KYULE, Jacob J. J. O. KONYANGO, Agnes O. NKURUMWA. Teachers in the implementation of practical agriculture curriculum in Kenya's arid and semi arid secondary schools

Table1. Mean technical knowhow on each agricultural practice that promotes DLA.

\begin{tabular}{|c|c|c|c|c|c|}
\hline TKH on Practices promoting DLA & $\mathbf{N}$ & Mean & Minimum & Maximum & Std Deviation \\
\hline Insitu water harvesting & 88 & 3.25 & 1.00 & 5.00 & 1.19 \\
\hline Use of sunken beds & 88 & 3.26 & 1.00 & 5.00 & 1.15 \\
\hline Grafting technology & 88 & 3.30 & 1.00 & 5.00 & 1.17 \\
\hline Preparation of micro catchments & 88 & 3.39 & 1.00 & 5.00 & 1.19 \\
\hline Improved fallowing & 88 & 3.39 & 1.00 & 5.00 & 1.09 \\
\hline Use of cultural water barriers & 88 & 3.50 & 1.00 & 5.00 & 1.07 \\
\hline Zero tillage & 88 & 3.51 & 1.00 & 5.00 & 1.12 \\
\hline Green houses and their use & 88 & 3.58 & 1.00 & 5.00 & 1.14 \\
\hline Rearing adaptable livestock species & 88 & 3.70 & 1.00 & 5.00 & 1.03 \\
\hline Construction of physical water barriers & 88 & 3.77 & 1.00 & 5.00 & 1.05 \\
\hline Pasture conservation measures & 88 & 3.83 & 2.00 & 5.00 & 0.91 \\
\hline Growing adaptable crop varieties & 88 & 3.88 & 2.00 & 5.00 & 1.03 \\
\hline Agroforestry & 88 & 3.90 & 1.00 & 5.00 & 1.05 \\
\hline Cover cropping & 88 & 3.93 & 1.00 & 5.00 & 1.06 \\
\hline Minimum tillage & 88 & 4.00 & 1.00 & 5.00 & 1.03 \\
\hline Methods of water harvesting & 88 & 4.00 & 1.00 & 5.00 & 0.97 \\
\hline Irrigation & 88 & 4.03 & 1.00 & 5.00 & 0.96 \\
\hline Mulching & 88 & 4.06 & 2.00 & 5.00 & 0.86 \\
\hline Crop rotation & 88 & 4.08 & 2.00 & 5.00 & 0.96 \\
\hline Timely planting & 88 & 4.19 & 1.00 & 5.00 & 0.90 \\
\hline
\end{tabular}

The respondents' mean technical knowhow on DLA practices was high at 3.7. The respondents had moderate technical knowhow on the following practices; insitu water harvesting, use of sunken beds, grafting technology, preparation of micro catchments and improved fallowing. Respondents had high technical knowhow on all the other practices that promote DLA. However, respondents did not record very low, low or very high mean technical knowhow on any of the agriculture practices. A study by Nina and Olga (2017) indicated that teachers' competence levels influence the manner in which they implement the curriculum. To implement secondary school agriculture curriculum in ASAL schools, agriculture teachers need to possess very high technical knowhow on all the DLA practices. Very high level of technical knowhow will make teachers be facilitators and managers of agriculture curriculum implementation process in ASAL schools. 
Miriam N. KYULE, Jacob J. J. O. KONYANGO, Agnes O. NKURUMWA. Teachers in the implementation of practical agriculture curriculum in Kenya's arid and semi arid secondary schools

IN THE $21^{\text {st }}$ CENTURY Vol. 76 , No. 4, 2018

540

\section{Training and Support}

Teacher training is an endless process that influences teacher quality. Preparation of competent human resource that is productive in the ASALs is dependent on the quality of the teacher. To be effective in implementing agriculture curriculum in ASAL schools, agriculture teachers need to be informed of current agricultural practices and knowledge promoting DLA. Thus, continuous professional advancement of agriculture teachers is necessary. Respondents were further asked to indicate the kind of support they received from their schools for professional development. Their responses were as presented in Figure 4. At school level 65.5 percent of agriculture teachers' received some form of skill and knowledge enhancement support. However, none of the forms of support directly addressed agriculture curriculum implementation. In addition 34.5 percent did not receive any form of agricultural skill and knowledge enhancement.

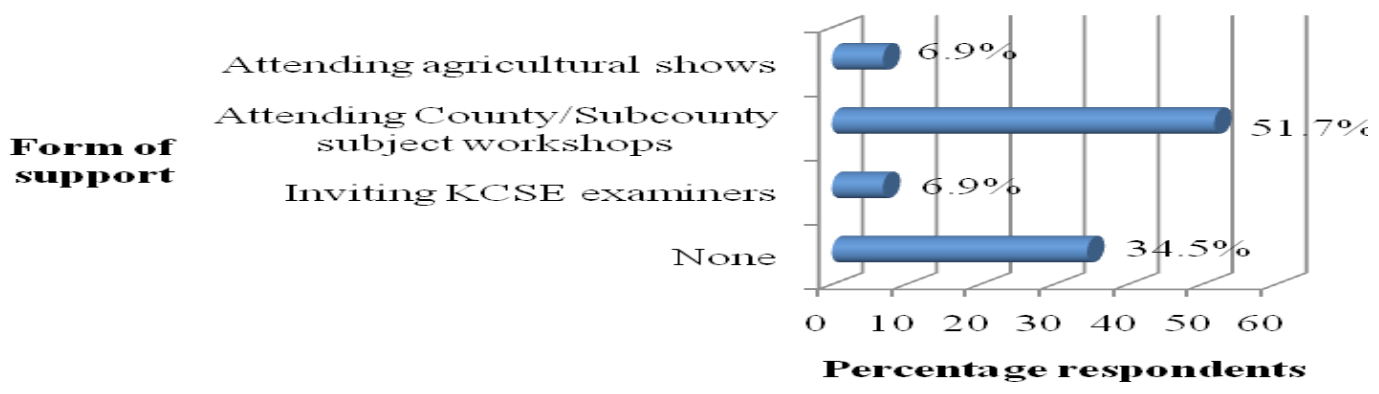

\section{Figure 4. Support towards professional development of agriculture teachers at school level.}

Past studies have shown that absence of continuous knowledge and skill enhancement for teachers impacts negatively on their potential to implement the curriculum (Olajide, Odoma, Okechukwu, Iyare \& Okhaimoh, 2015). Skill and knowledge are the highest concern for an agriculture teacher. Continuous professional development is not only for the teacher's benefit but also for the learners and the entire society. The failure of agriculture curriculum to address the agricultural activities in ASALs could be explained by failure to continuously foster knowledge and skill enhancement by the agriculture teachers. Continuous empowerment of the teacher through knowledge and skill acquisition serves as an intrinsic motivation to change their curriculum implementation strategies. In this study, the change is towards implementing the agriculture curriculum for the benefit of the ASAL schools and communities. An empowered teacher is enthusiastic in teaching, committed to teaching and spends more time with their learners. Empowering agriculture teacher in ASAL schools is inevitable since technology has taken over in all sectors. Empowerment helps the teachers to adjust agriculture curriculum implementation strategies to keep pace with technological changes and remain relevant to ASALs.

\section{Discussion}

Teachers are essential in the implementation of agriculture curriculum in ASAL schools. The aim of this research was to document teacher related factors which influence agriculture curriculum implementation. These factors included; teacher's ability to translate curriculum objectives into learning experiences relevant to DLA which was attributed to their training level, the teachers' technical knowledge and skills regarding practices promoting DLA in the curriculum and training and support. 
From the research results, most of the respondents are professionally trained with the majority being holders of diploma or degree while a few were certificate holders. This finding is an indication that the majority of the personnel implementing the agriculture curriculum in ASALs are trained and qualified to do so. A study by Sindale and Dlamini, (2013) found out that qualified agriculture teachers appropriately interpret the syllabus and are able to determine the appropriate concepts to pass to learners. Agriculture teachers' training level is expected to influence agricultural activities in the surrounding communities, yet this is to be achieved despite majority of the teachers implementing the curriculum being trained and qualified.

However, one quarter of the teachers were not professionally qualified to handle agriculture curriculum implementation at secondary school level. The presence of untrained teachers implementing the curriculum in secondary schools contradicts the Government's promise on ensuring that all schools had trained teachers (Ministry of Education, Science and Technology, 2005). The presence of untrained teachers implementing agriculture curriculum in ASAL secondary school compromises the implementation process as the quality and relevance of agriculture curriculum depends on the competence of the curriculum implementers (Konyango \& Asienyo, 2015). Thus, inability to interpret curriculum objectives appropriately to address the societal needs influences the quality of agricultural skills and knowledge transferred to the learners. Untrained teachers' poor interpretation of curriculum objectives in ASAL schools is one of the possible reasons that have led to under exploitation of the agricultural potential in ASALs.

Agriculture teachers were found to have high levels of technical knowhow on some of the DLA practices and hence are able to carry out these practices and expose the learners such practices that promote ASAL agriculture. In situ water harvesting, use of sunken beds and grafting technology were some of the practice where teachers indicated moderate technical knowhow. ASALs being areas of drought accompanied with water shortage, the skill of insitu water harvesting technique and use of sunken beds is paramount since they help retain water in the soil longer for crop use. Grafting technology promotes fast maturation of crops especially fruits. It is an agricultural skill that can improve agricultural production in ASALs. The level of technical knowhow on all the individual DLA practices points to an inadequacy among agriculture teachers implementing the curriculum in ASAL schools. Thus, ASALs continue to be under exploited despite agriculture curriculum being implemented in ASAL schools.

Agriculture teachers in ASALs receive insufficient support from schools for professional development. Of those that did get support, the support was not aimed at enhancing their knowledge and skills towards implementation of DLA practices in ASAL schools. Thus, there is need for continuous training for teachers in order to remain relevant and be motivated to implement the curriculum in ASAL schools. Failure to continiously support and train agriculture teachers has contributed to the lagging behind of the ASALs agriculturally since such teachers are unable to effectively implement DLA practices that promote ASAL agriculture.

Implementation of agriculture curriculum in Kenya's ASAL secondary schools is yet to influence agricultural activities in the surrounding communities. Compared to some developed countries such as the United States of America, where agricultural institutions have taken charge of providing leadership and human resource development among the learners of agriculture at secondary school level and Kenya can borrow from them (Kanyi, Vandenbosch, Ngesa \& Kibett, 2011). Agriculture teachers need to be well trained, possess high technical knowledge and skills on DLA practices and their professional development, be continuously supported by the ASAL institutions. Such support will offer teachers the necessary competence to prepare secondary school agriculture graduates with knowledge and skills to exploit the agricultural potential in ASALs hence enhancing ASAL economic development.

\author{
PROBLEMS \\ OF EDUCATION \\ IN THE $21^{\text {st }}$ CENTURY \\ Vol. 76, No. 4, 2018 \\ 541
}


Miriam N. KYULE, Jacob J. J. O. KONYANGO, Agnes O. NKURUMWA. Teachers in the implementation of practical agriculture curriculum in Kenya's arid and semi arid secondary schools

\author{
PROBLEMS \\ OF EDUCATION \\ IN THE $21^{\text {st }}$ CENTURY \\ Vol. 76, No. 4,2018 \\ 542 Conclusions
}

To respond to the dynamic educational needs and demands of the $21^{\text {st }}$ century, training of teachers remains paramount. Teacher training continues to receive more emphasis around the world since training provides the teacher with the fundamentals of curriculum implementation. Findings from this study suggest that, untrained teachers are implementing agriculture curriculum in ASAL schools. The implication of this lack of training is ineffective implementation of the agriculture curriculum due to inability to appropriately interpret the curriculum objectives into suitable learning experiences that serve ASAL needs. The implementation process thus produces incompetent agriculture graduates who are unable to positively influence agricultural activities both at school and in the surrounding community, hence ASALs agricultural potential is underexploited.

Agriculture teachers require more technical knowhow on practices promoting DLA to increase efficiency in implementing agriculture curriculum in ASALs. Agriculture teachers in ASAL schools are not exposed to regular trainings that are relevant in agriculture curriculum implementation. Thus, there is a need for continuous professional development for agriculture teachers to enhance their technical knowhow on DLA practices and the ability to translate curriculum objectives to learning activities relevant to ASALs.

These findings are important to the Government of Kenya to give priority to employment of trained teachers in ASAL counties not only in agriculture but across all subjects. The findings inform agriculture training program developers to come up with professional development programmes promoting acquisition of technical knowhow on all the DLA practices. Agricultural extension officers need to emphasize on insitu water harvesting, use of sunken beds, grafting, preparation of micro-catchments and improved fallowing in their extension work in ASAL areas for better agricultural productivity.

Context specific research and training is vital to identify areas for improvement and so inform dynamic responses to educational training and development needs appropriate for each context.

\title{
Acknowledgement
}

The author's gratitude and appreciation goes to Dr. Jacob J. J. O. Konyango and Dr. Agnes O. Nkurumwa for their invaluable input in preparation of the larger work from which this manuscript was extracted. To Deutscher Akademischer Austausch Dienst (DAAD), your financial support towards the large part of this work was timely and fruitful. To Mr. Raphael Kasyoka and Mr. Joseph Cherutich who were very instrumental during data collection for this work.

\section{References}

Fraenkel, J., \& Wallen, N. (2000). How to design and evaluate research in education (4 $4^{\text {th }}$ Ed.). New York. McGraw Hill Higher Education.

Government of Kenya, (1981). Mackay Commission: The presidential working party. Nairobi: Government printers.

Government of Kenya, (1976). The report of the national committee on educational objectives and policies. Nairobi: Government Printer.

Kamau T. N., \& Orodho, J. A. (2014). Secondary school student's perception towards agriculture subject in public secondary schools in Nairobi County, Kenya. Journal of Humanities and Social Science, 19 (7), 30-36.

Kirima, T. M., \& Kinyua, S. M., (2016). Teacher related factors influencing students' enrollment in biology subject in public secondary schools in Meru Central Sub-County in Kenya. Journal of Education and Practice, 7 (2),130-136.

Konyango, J. J. J. O., \& Asienyo, B. O. (2015). Secondary school agriculture: Participatory approaches to the implementation of secondary school agriculture curriculum in Kenya between1959 and 2012. International Journal of Scientific Research and Innovative Technology, 2 (1), 1-11. 
Miriam N. KYULE, Jacob J. J. O. KONYANGO, Agnes O. NKURUMWA. Teachers in the implementation of practical agriculture curriculum in Kenya's arid and semi arid secondary schools

Konyango, J. J. J. O. (2014). Secondary school agriculture curriculum policies in Kenya 1959 \& 2004. Lap Lambert Academic Publishing. Saarbrucken, Germany.

Lewa, K. K., \& Ndungu, J. M. (2012). Does educational level influence the choice of farming as a livelihood career? Results of an empirical study from coastal lowland Kenya. Retrieved on 4-102013 from $w w w$. future-agriculture.

Lukman, A. N., (2012). Comparison of one-stage, two-stage, and three-stage estimators using finite population. The Pacific Journal of Science and Technology, 13 (2), 166-171.

Mapolisa, T., \& Tshabalala, T. (2013). Attitudes of teachers towards the policy of teaching practical/ vocational subjects. International Journal of Asian Social Science, 3 (11), 2267-2278.

Ministry of Education, Science and Technology, (2005). Kenya Education Sector Support Programme 2005 - 2010. Nairobi: Government printers.

Ministry of State for Development of Northern Kenya and other Arid Lands, (2011). Vision 2030 Development Strategy for Northern Kenya and other dry areas. Retrieved on 16-04-2014 from www.disasterriskreduction.net.

Moore, G. E. (1979). Back to the basics in teaching agriculture: The project plan. Purdue University West Lafayette IN: Agricultural Education Magazine, April 1979 pp 219-220.

Mwiria, K. (2002). Vocationalization of secondary education: Kenya case study. Kimkam Development Consultants (Africa) Ltd. Retrieved on 4/11/2013 from http://www.ijhssnet.com/journals/ 3_No (9) 13.

Nina, R., \& Olga, O. (2017). In-service training of teachers of English as a foreign language in Estonia: Mapping of trends and opportunities. Problems of Education in the $21^{\text {st }}$ Century, 75 (2), 194-203.

Obonya, P. (2004). Education for the knowledge economy. Ibadan, Mosuro Publishers.

Ofoha, D., Uchegbu, C. N., Anyikwa, B., \& Nkemdirim, M. (2009). A critical appraisal of the mode of implementation of Nigerian secondary school curriculum: Towards socio-economic empowerment of youth. Retrieved on 25/03/2015 from www.ernwaca.org/.

Okogu, J. (2011). Factors affecting the effective implementation of social studies curriculum in Delta State teachers' training colleges. Journal of Research in Education and Society, 2 (3), 48-53.

Olajide, K., Odoma, M. O., Okechukwu, F., Iyare, R., \& Okhaimoh, K. I. (2015). Problems of teaching agricultural practical in secondary schools in Delta State, Nigeria. International Journal of Innovative Education Research, 3 (2), 7-19

Owoeye, J. S., \& Yara, P. O. (2011). School facilities and academic achievement of secondary school agricultural science in Ekiti State, Nigeria. Asian Social Science, 7 (7), 64-74. doi:10.5539/ass. v7n7p64.

Puyate, S. T. (2012). Constraints to the effective implementation of vocational education program in private secondary schools in Port Harcourt local government area. Asian- Pacific Journal of Cooperative Education, 9 (1), 59-71.

Reche, G. N., Bundi, T. K., Riungu, J. N., \& Mbugua, Z. K. (2012). Factors contributing to poor performance in Kenya certificate of primary education in public day primary schools in Mwimbi Division, Maara District, Kenya. International Journal of Humanities and Social Science, 2 (5), 127-133.

Sindale, B. N., \& Dlamini, B. M. (2013). Curriculum reforms and competence level of high school agriculture teachers in Swaziland. Journal of International Agricultural Extension Education, 20 (3), 33-44.

UNDP, (2012). National report on drought risk reduction policies and programmes. Retrieved on 13-082012 from http://mirror.undp.org.

Received: May 14, 2018

Accepted: August 04, 2018

\begin{tabular}{|ll|}
\hline Miriam N. Kyule & $\begin{array}{l}\text { Lecturer, Egerton University, 20115 Egerton, Kenya. } \\
\text { E-mail: kyule11@gmail.com }\end{array}$ \\
\hline Jacob J. J. O. Konyango & Machakos University, Kenya. \\
& E-mail: jaonyango2003@yahoo.com \\
\hline \multirow{2}{*}{ Agnes O. Nkurumwa } & $\begin{array}{l}\text { Egerton University, Nakuru, Kenya. } \\
\text { E-mail: aonkurumwa@yahoo.com }\end{array}$ \\
\hline
\end{tabular}

PROBLEMS
OF EDUCATION
IN THE 21 $21^{\text {st }}$ CENTURY
Vol. 76, No. 4,2018

543 